\title{
Development of Solid-Phase Extraction for Triazines: Application to a Biological Sample
}

\author{
Joseane M. Pozzebon, ${ }^{1}$ Sônia C. N. Queiroz, ${ }^{2}$ and \\ Isabel C. S. F. Jardim ${ }^{1} *$ \\ ${ }^{1}$ Department of Analytical Chemistry, Chemistry Institute, \\ State University of Campinas, Campinas, SP, Brazil \\ ${ }^{2}$ Embrapa Environment, Jaguariúna, SP, Brazil
}

\begin{abstract}
A sensitive extraction method for the concentration of the triazines simazine, atrazine, and ametryn was developed and applied to a biological sample (urine). After protein precipitation with acetonitrile, a further purification using solid-phase extraction (SPE) was carried out. The samples were then analysed by high performance liquid chromatography (HPLC) using a $\mathrm{C}_{18}$ column and an acetonitrile-water $(40: 60, \mathrm{v} / \mathrm{v})$ mobile phase. The $\mathrm{pH}$ of the mobile phase was adjusted to 9.0 with $\mathrm{NH}_{4} \mathrm{OH}$, the flow-rate was $0.5 \mathrm{~mL} / \mathrm{min}$ and $\mathrm{UV}$ detection was at $220 \mathrm{~nm}$. Recovery values were satisfactory and the method developed can be used
\end{abstract}

\footnotetext{
${ }^{*}$ Correspondence: Isabel C. S. F. Jardim, Department of Analytical Chemistry, Chemistry Institute, State University of Campinas, P.O. Box 6154 13084-971 Campinas, SP, Brazil; E-mail: icsfj@iqm.unicamp.br.
}

781

DOI: $10.1081 /$ JLC-120018422

Copyright (C) 2003 by Marcel Dekker, Inc.
1082-6076 (Print); 1520-572X (Online) www.dekker.com 
MARCEL DeKKer, INC. • 270 MAdison AVENUE • NEW YoRK, NY 10016

(92002 Marcel Dekker, Inc. All rights reserved. This material may not be used or reproduced in any form without the express written permission of Marcel Dekker, Inc.

for monitoring urine samples of workers exposed to simazine, atrazine, and ametryn, in forensic, veterinary, and environmental toxicologies.

Key Words: Triazine; Solid-phase extraction; Urine; High performance liquid chromatography.

\section{INTRODUCTION}

Currently, there is much concern about the exposure of humans to pesticides in general. ${ }^{[1]}$ Although, most people are not occupationally exposed to pesticides, nearly everyone has some level of exposure resulting from food, air, water, or dermal contact. Many studies have been conducted to determine the possibility of a causal relationship between pesticides and health outcomes, such as lymphoma, soft tissue sarcoma, breast cancer, and endocrine disruption effects. ${ }^{[1]}$ Because of the widespread use of the pesticides, the need exists for accurate bio-monitoring methods to assess exposure to the pesticides.

The analysis of pesticides in biological samples by high performance liquid chromatography (HPLC) is usually difficult, owing to the large number of substances present in the samples and because the compounds of interest are often present in very low concentrations. Thus, two main problems are associated with direct injection: high adsorption of some proteins on the column, and rapid pressure build-up at the head of the column owing to protein denaturation and adsorption. As a result, resolution decreases and the column lifetime is greatly shortened. ${ }^{[2]}$ Therefore, both sample clean-up and enrichment of the investigated compounds should be carried out prior to analysis. $^{[2,3]}$

To resolve these problems, a number of sample preparation techniques have been described for removing proteins prior to injection of the sample. These include the use of pre-columns, ultrafiltration devices, and various protein precipitants, such as organic solvents or ionic salts. ${ }^{[4]}$ Conventional liquid-liquid extraction (LLE) methods with organic solvents are useful for analysis of pesticides and poisons, because the chemical to be analyzed is not lost during the procedure, but is contained in at least one of the fractions separated. Although, LLE proved to be suitable in a substantial number of cases, the disadvantages of this technique, e.g., matrix interferences, emulsion formation, and use of large volumes of hazardous solvents, have troubled the analyst. ${ }^{[5,6]}$ In addition, this technique has proved difficult to automate efficiently. ${ }^{[7]}$

Solid-phase extraction (SPE) offers several distinct advantages over traditional LLE. The main advantages are higher selectivity, since a large number of sorbents and solvents can be chosen for various applications, 
cleaner extracts, since the analytes can be selectively retained on and eluted from the column; and more reproducible results. One of the major advantages is that the extraction procedure can be automated. ${ }^{[8-10]}$ On the other hand, there are also some drawbacks to SPE. One of them is that frozen and thawed biological samples may contain solid particles that can block the cartridges/columns. However, the use of specially constructed frits or pre-filters can solve this problem. In addition, there are still problems with batch-to-batch reproducibility and with irreversible adsorption onto the sorbent. ${ }^{[5]}$

Triazine herbicides are used extensively in agriculture for pre and postemergence weed control and algicides. ${ }^{[11,12]}$ Triazines are probably the most throughly studied and the most representative of this class of contaminants, as they are known carcinogens. Exposure to these compounds involves a potential health risk. There is also a possibility of suicidal ingestion of triazines. The acute toxicity of triazines is generally low for mammalian species, but they are highly toxic to rats (acute oral $\mathrm{LD}_{50}, 180-334 \mathrm{mg} / \mathrm{kg}$ ). Chronic lethal toxicity was reported for simazine in sheep (3 daily doses of $250 \mathrm{mg} / \mathrm{kg}$ and 31 daily doses of $100 \mathrm{mg} / \mathrm{kg}$ ) and in crows (3 daily levels of $250 \mathrm{mg} / \mathrm{kg}$ ) and for atrazine in crows. ${ }^{[13]}$

Although a few papers have reported the isolation of triazines with the use of $\mathrm{C}_{18}$ cartridges, ${ }^{[13]}$ they were limited to environmental samples, such as water and soil. In this paper, we present a simple isolation method using $\mathrm{C}_{18}$ cartridges for simultaneous quantification of the pesticides simazine, atrazine, and ametryn in human urine by HPLC. To our knowledge, a similar methodology has not been described. The structures and commercial names for these herbicides are shown in Table 1.

During method development, a most important step is validation. In this work, method validation was applied to the HPLC determination of the herbicides

Table 1. Chemical structures of the triazines used in the present study.

\begin{tabular}{lccc}
\hline & & & \\
& & & \\
& Simazine & Atrazine & Ametryn \\
\hline $\mathrm{R}_{1}$ & $\mathrm{Cl}$ & $\mathrm{Cl}$ & $\mathrm{SCH}_{3}$ \\
$\mathrm{R}_{2}$ & $\mathrm{C}_{2} \mathrm{H}_{5}$ & $\mathrm{C}_{2} \mathrm{H}_{5}$ & $\mathrm{C}_{2} \mathrm{H}_{5}$ \\
$\mathrm{R}_{3}$ & $\mathrm{C}_{2} \mathrm{H}_{5}$ & $\mathrm{i}-\mathrm{C}_{3} \mathrm{H}_{7}$ & i- $\mathrm{C}_{3} \mathrm{H}_{7}$ \\
\hline & & & \\
\hline
\end{tabular}


simazine, atrazine, and ametryn, after optimization of the extraction and chromatographic separation conditions. The parameters involved were precision, recovery, detection and quantification limits, analytical curve, and linear limits.

\section{EXPERIMENTAL}

\section{Materials}

Standards of the triazines, simazine $(98.3 \%)$, atrazine $(97.7 \%)$, and ametryn (96.8\%) were obtained from Novartis. The solvents, acetonitrile (Mallinckrodt) and chloroform (Mallinckrodt) were chromatographic grade. Phosphoric acid (Synth) and ammonioum hydroxyde (Synth) were analytical reagent grade. Purified water was obtained from a Millipore Milli-Q Plus system.

The extraction cartridges were Envi $\mathrm{C}_{18}$, Supelclean (Supelco), packed with $500 \mathrm{mg}$ silica-octadecyl $\left(\mathrm{C}_{18}\right)$.

Stock solutions of each herbicide were prepared in methanol at concentrations of $104.4 \mu \mathrm{g} / \mathrm{mL}, 101.4 \mu \mathrm{g} / \mathrm{mL}$, and $104.4 \mu \mathrm{g} / \mathrm{mL}$, for simazine, atrazine, and ametryn, respectively. The solutions used to construct the analytical curves and to spike the samples were prepared in mobile phase at a concentration of $1000 \mu \mathrm{g} / \mathrm{L}$ of each herbicide and stored in the refrigerator at $4{ }^{\circ} \mathrm{C}$, where the stock solutions are stable for 60 days.

The analytical curve involved eight different concentrations: 20, 40, 80, $100,200,300,500$, and $600 \mu \mathrm{g} / \mathrm{L}$, of each analyte, and the injections were made in three replicates.

\section{Urine Collection and Storage}

Urine samples (blank) from human volunteers were collected and kept frozen at $-20^{\circ} \mathrm{C}$ until the analysis. After the urine samples had been thawed, they were shaken to homogenize the sample. The required volume was then sampled as quickly as possible to avoid sedimentation of any deposit.

\section{Procedure}

Two milliliter of urine sample were fortified by addition of a predetermined volume of the $1000 \mu \mathrm{g} / \mathrm{L}$ of solution containing the herbicides simazine, atrazine, and ametryn, resulting in three levels of fortification: 80 , 100 , and $150 \mu \mathrm{g} / \mathrm{L}$. The sample was basified by addition of $200 \mu \mathrm{L}$ of $\mathrm{NH}_{4} \mathrm{OH}$ to $\mathrm{pH} \sim 9$, diluted with $4 \mathrm{~mL}$ of acetonitrile and deproteinized by centrifugation $(5 \mathrm{~min}, 3000 \mathrm{~g})$. Three milliliter aliquots of the supernatant containing 
urine : acetonitrile $(1: 2 \mathrm{v} / \mathrm{v})$ were separated and diluted to $20 \mathrm{~mL}$ with Milli-Q water for the extraction procedure.

The sample was percolated through the SPE cartridges under vacuum at a rate of $3 \mathrm{~mL} / \mathrm{min}$. Before sample application, the SPE cartridges were conditioned with $10 \mathrm{~mL}$ of methanol and equilibrated with $5 \mathrm{~mL}$ of Milli-Q water. After the sample had passed through the cartridge by vacuum, the cartridge was washed with $5 \mathrm{~mL}$ of Milli-Q water; this eluate was discarded and the sorbent bed dried under vacuum for $3 \mathrm{~min}$. The analytes were then eluted with $3 \mathrm{~mL}$ of chloroform. The solvent was evaporated to dryness under a stream of nitrogen and the residue was dissolved in $200 \mu \mathrm{L}$ of acetonitrile. The injection volume was $10 \mu \mathrm{L}$.

\section{Equipment}

Chromatography was performed with a modular HPLC system equipped with a Rheodyne $7725 \mathrm{i}$ injector with a $10 \mu \mathrm{L}$ loop, a Waters 510 pump, an UV/Vis absorbance detector (Waters Model 486) coupled to a Chrom Perfect for Windows, version 3.03, program in a PC-compatible microcomputer, for acquisition and treatment of data. The column $(150 \times 3.9 \mathrm{~mm}$ i.d. $)$ and guard column $(20 \times 3.9 \mathrm{~mm}$ i.d. $)$ were Waters Nova-Pak C-18, $4 \mu \mathrm{m}$. All measurements were carried out at room temperature.

The mobile phase was acetonitrile $: \mathrm{H}_{2} \mathrm{O}(40: 60, \mathrm{v} / \mathrm{v})$. The $\mathrm{pH}$ was adjusted at 9.0 with $\mathrm{NH}_{4} \mathrm{OH}$ using a Digimed, model DM21, $\mathrm{pH}$ meter, with glass and thermal compensation electrodes. The mobile phase flow-rate was set at $0.5 \mathrm{~mL} / \mathrm{min}$ and UV detection was at $220 \mathrm{~nm}$.

The samples were centrifugated using an Excelsa ${ }^{\circledR}$ Centrifuge, model MP-Fanem.

\section{RESULTS AND DISCUSSION}

The separation of the triazine herbicides was tested at various compositions of the eluent and at different $\mathrm{pH}$ values. Due to their polar character, the triazines do not interact strongly with the $\mathrm{C}_{18}$ reversed phase, the most important stationary phase utilized in HPLC. Thus, it is necessary to add $\mathrm{NH}_{4} \mathrm{OH}$ to the mobile phase to increase triazine retention. The triazine derivatives are classified according to their substituents in position 2 for the chloro and methylthio derivatives. The retention time decreases with increasing polarity of these substituents: $-\mathrm{Cl}<-\mathrm{SCH}_{3}<-\mathrm{OCH}_{3}$. The retention time also increases with increasing size of the alkyl groups in positions 4 and 6 , e.g. simazine elutes before atrazine and ametryn. Figure 1 shows a chromato- 
a)

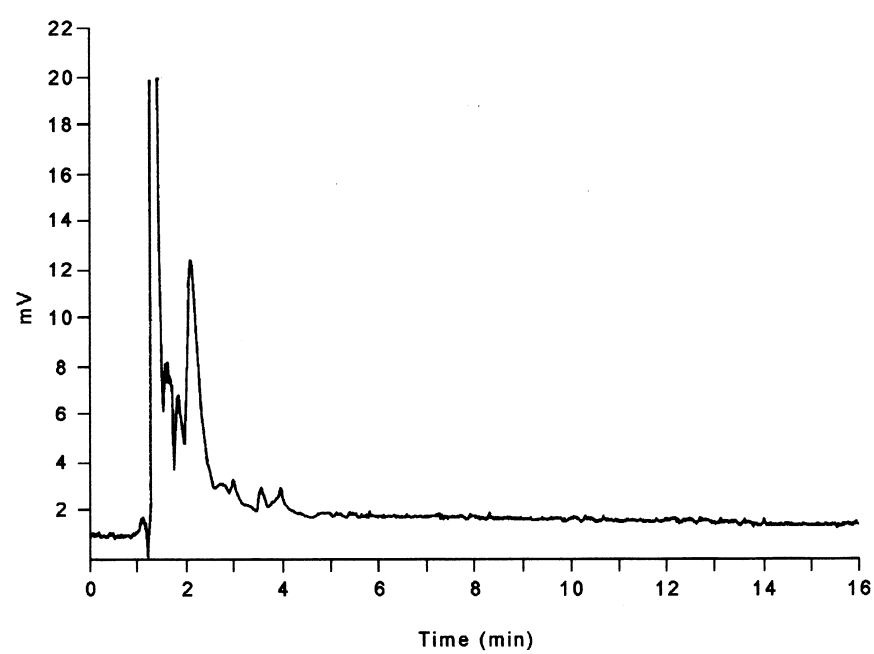

b)

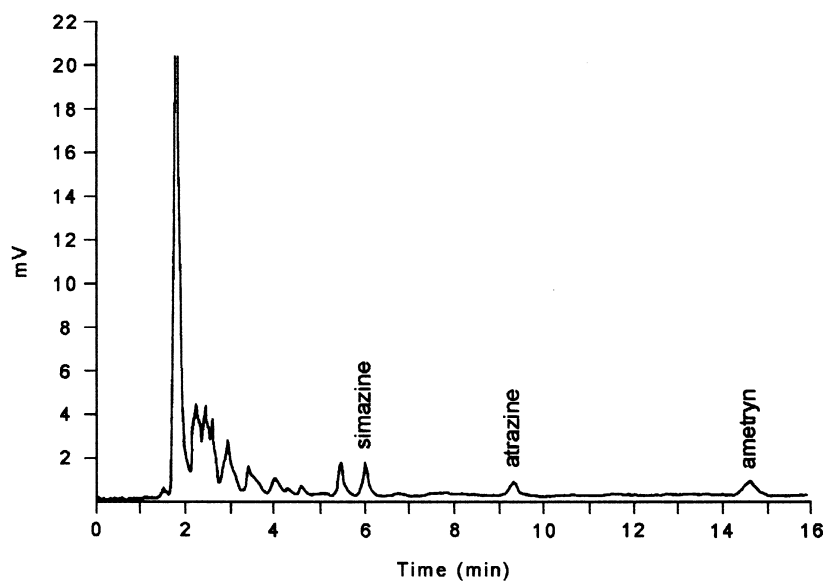

Figure 1. Chromatograms obtained after SPE extraction, (a) blank urine, (b) sample spiked with $80 \mu \mathrm{g} / \mathrm{L}$ of the triazines. Conditions: analytical $(150 \times 3.9 \mathrm{~mm})$ and guard $(20 \times 3.9 \mathrm{~mm})$ columns: Nova Pak $\mathrm{C}_{18}(4 \mu \mathrm{m})$; mobile phase $\mathrm{ACN}: \mathrm{H}_{2} \mathrm{O}(40: 60, \mathrm{v} / \mathrm{v})$ adjusted with $\mathrm{NH}_{4} \mathrm{OH}$ to $\mathrm{pH}$ 9; flow-rate: $0.5 \mathrm{~mL} / \mathrm{min}$; detection: $\mathrm{UV}$ at $220 \mathrm{~nm}$; injection volume: $10 \mu \mathrm{L}$. 
gram of a urine blank and a urine sample spiked with the three herbicides at $80 \mu \mathrm{g} / \mathrm{L}$.

In previous reports, the herbicides were isolated from biological or environmental samples by repeated extraction with organic solvents and centrifugation, a more complicated and time-consuming process. ${ }^{[11]}$ In the present investigation, the $\mathrm{C}_{18}$ cartridges were eluded with methanol or with chloroform. Recoveries were generally satisfactory for both solvents, but backgrounds were cleaner with chloroform. The evaporation time for the chloroform eluate was shorter than that for the methanol eluate. Therefore, the use of chloroform as an elution solvent is recommended for the present triazines.

The linearity of an analytical method is its ability, within a definite range, to obtain results directly proportional to the concentration (quantities) of the analyte in the sample. ${ }^{[14]}$ The linear regression equation $(y=a+b x)$ parameters for atrazine, simazine, and ametryn calibrations are presented in Table 2. All three analytes showed correlation coefficients $>0.999$.

Precision is one of the most important criteria for judging the performance of an analytical method. The precision of the analysis is estimated as the relative standard deviation (RSD) of measured concentrations of replicate samples. When analyses of the spiked control samples are carried out in the same assay run or on the same day, the precision data are reported as intraassay precision, as compared to inter-assay precision for which the analyses are performed on different days.

Table 3 shows the intra-assay and inter-assay precisions of the method. The results show acceptable precisions, with RSD values between 2.2 and $15 \%$. For biological samples, a RSD up to $15 \%$ is acceptable. ${ }^{[15,16]}$

The recoveries were obtained by analyzing, in triplicate, urine spiked with each compound in three levels of fortification, and by comparing peak areas with those produced by the analysis of a known amount of the pure standard of each compound.

Table 2. Analytical curves and linearities for the triazines.

\begin{tabular}{lcccc}
\hline & \multicolumn{3}{c}{ Analytical curve } & \\
\cline { 2 - 4 } Herbicide & $a$ & $b$ & $r$ & Linear interval $(\mu \mathrm{g} / \mathrm{L})$ \\
\hline Simazine & 48.7 & 130.4 & 0.9997 & $40-600$ \\
Atrazine & 58.7 & 177.6 & 0.9999 & $30-600$ \\
Ametryn & 47.8 & 142.5 & 0.9999 & $40-600$ \\
\hline
\end{tabular}

Note: $y=a+b x, a=$ linear coefficient, $b=$ angular coefficient, $r=$ correlation coefficient. 
Table 3. Precision (intra and inter-assay) and recovery of triazines at three concentration levels $(n=3)$.

\begin{tabular}{lcccc}
\hline Herbicide & $\begin{array}{c}\text { Fortification } \\
(\mu \mathrm{g} / \mathrm{L})\end{array}$ & $\begin{array}{c}\text { Recovery } \\
(\%)\end{array}$ & $\begin{array}{c}\text { Precision } \\
\text { intra-assay } \\
\text { RSD }(\%)\end{array}$ & $\begin{array}{c}\text { Precision } \\
\text { inter-assay } \\
\text { RSD }(\%)\end{array}$ \\
\hline Simazine & 80 & 76 & 10 & \\
& 100 & 78 & 7.2 & 9.7 \\
Atrazine & 150 & 70 & 8.8 & \\
& 80 & 76 & 11 & 15 \\
Ametryn & 100 & 82 & 9.3 & \\
& 150 & 73 & 9.8 & 11 \\
& 80 & 74 & 2.2 & \\
\hline
\end{tabular}

Note: $n=$ number of replicates.

The average results obtained for herbicide recoveries (Table 3) ranged from $70 \%$ to $82 \%$, recoveries which are considered acceptable for biological matrices. $^{[16]}$

The detection limit (LOD) is the lowest concentration of an analyte in a sample that can be detected, not quantified. It is expressed as a concentration in terms of signal-to-noise ratio, usually three times the noise level. The quantitation limit (LOQ) is the lowest concentration of an analyte in a sample that can be determined with acceptable precision and accuracy under the stated operational conditions of the method. ${ }^{[16]}$ Like LOD, LOQ is expressed as a concentration, with the precision and accuracy of the measurement also reported. Usually, ten times the noise level is used to determine LOQ. Table 4 shows the values of LOD and LOQ for the analytes for the instrumentation and for the method, after a 5 -fold pre-concentration step.

Table 4. Detection and quantification limits for the triazine herbicides.

\begin{tabular}{lcccc}
\hline Herbicide & LOD $(\mu \mathrm{g} / \mathrm{L})$ & LOQ $(\mu \mathrm{g} / \mathrm{L})$ & LOD $^{\mathrm{a}}(\mu \mathrm{g} / \mathrm{L})$ & $\mathrm{LOQ}^{\mathrm{a}}(\mu \mathrm{g} / \mathrm{L})$ \\
\hline Simazine & 13 & 40 & 2.6 & 8.0 \\
Atrazine & 10 & 30 & 2.0 & 6.0 \\
Ametryn & 13 & 40 & 2.6 & 8.0 \\
\hline
\end{tabular}

${ }^{\mathrm{a}} \mathrm{LOD}$ and LOQ after 5 -fold pre-concentration step; $n=3$ for all measurements. 


\section{CONCLUSION}

The results of this study indicate that the SPE procedure is an effective extraction method for these basic compounds. The advantages are better reproducibility and less labor, when compared with liquid-liquid extraction.

The parameters obtained for validation: analytical curve, linearity, recovery, and precision, showed that this is a rapid, efficient, and simple method, since the proposed method offers both the sensitivity and selectivity required to detect simazine, atrazine, and ametryn in urine by HPLC.

Thus, the present method for triazine herbicides, using $\mathrm{C}_{18}$ cartridges together with HPLC, seems useful in forensic, clinical, veterinary, and environmental toxicologies.

\section{ACKNOWLEDGMENTS}

The authors acknowledge financial support and a fellowship from the Fundacuão de Amparo à Pesquisa do Estado de São Paulo (FAPESP). We also thank C. H. Collins for helpful discussions and suggestions.

\section{REFERENCES}

1. Beeson, M.D.; Driskell, W.J.; Barr, D.B. Anal. Chem. 1999, 71, 3526-3530.

2. Falcó, P.C.; Hernández, R.H.; Cabeza, A.S. J. Chromatogr. 1993, 619, 177-190.

3. Queiroz, S.C.N.; Collins, C.H.; Jardim, I.C.S.F. Quim. Nova 2001, 24, 68.

4. Blanchard, J. J. Chromatogr. 1981, 226, 455-460.

5. Lingeman, H.; Hoekstra-Oussoren, S.J.F. J. Chromatogr. B 1997, 689, 221-237.

6. Franke, J.P.; Zeeuw, R.A. J. Chromatogr. B 1998, 713, 51-59.

7. Turnell, D.C.; Cooper, J.D.H. J. Chromatogr. 1989, 492, 59.

8. Suzuki, O.; Seno, H.; Ishii, A. Forens. Sci. Int. 1996, 80, 137-146.

9. Chen, X.H.; Wijsbeek, J.; Franke, J.P.; Zeeuw, R.A. J. Forens. Sci. 1992, 37, 61-71.

10. Chen, X.H.; Wijsbeek, J.; Ensing, K.; Franke, J.P.; Zeeuw, R.A. J. Chromatogr. 1993, 613, 289-294.

11. Coquart, V.; Hennion, M.C. J. Chromatogr. 1991, 585, 67.

12. Durand, G.; Barceló, D. J. Chromatogr. 1990, 502, 275. 
13. Kumazawa, T.; Sato, K.; Seno, H.; Suzuki, O. Forens. Sci. Int. 1992, 54, 159-166.

14. Hubert, Ph.; Chiap, P.; Crommen, J.; Boulanger, B.; Chapuzer, E.; Mercier, N.; Martin, S.B.; Chevalier, P.; Grandjean, D.; Lagorce, P.; Lallier, M.; Laparra, M.C.; Laurentie, M.; Niver, J.C. Anal. Chim. Acta 1999, 391, 135-148.

15. Chasin, A.A.M.; Chasin, M.; Salvador, M.C. Rev. Farm. Bioquim. 1994, 30, 49-53.

16. Jenke, D.R. Instr. Sci. Tecnhnol. 1998, 26, 1-18.

Received August 27, 2002

Accepted October 1, 2002

Manuscript 5951 
Copyright $\odot 2003$ EBSCO Publishing 
Copyright of Journal of Liquid Chromatography \& Related Technologies is the property of Taylor \& Francis Ltd and its content may not be copied or emailed to multiple sites or posted to a listserv without the copyright holder's express written permission. However, users may print, download, or email articles for individual use. 